\title{
急性胆囊炎を併発した胆囊癌の検討
}

\begin{tabular}{lllllllr}
\multicolumn{8}{c}{ 県西部浜松医療センター外科 } \\
宇野 & 武治 & 内村 & 正幸 & 脇 & 慎治 & 木田 & 栄郎 \\
神田 & 和弘 & 水町 & 信行 & 山田 & 護 & 矢次 & 孝 \\
鈴木 & 昌八 & 岡田 & 朋久 & & & &
\end{tabular}

\section{CARCINOMA OF THE GALLBLADDER PRESENTING AS ACUTE CHOLECYSTITIS}

Takeji UNO, Masayuki UCHIMURA, Shinji WAKI, Hideo KIDA Kazuhiro KANDA, Nobuyuki MIZUMACHI, Mamomu YAMADA, Takashi YATSUGI, Shohachi SUZUKI and Tomohisa OKADA

Hamamatsu Medical Center

索引用語：胆囊癌，急性胆囊炎，経皮経肝的胆囊ドレナージ

はじめに

胆囊癌の治療成績は, 他の消化器癌に比べて極めて 不良である。その原因は胆囊癌の術前診断が困難なこ とと，適切な根治術式が一定していないことに起因す る. 1980年, 横山ら の全国集計によれば, 2,269例の 手術例中根治切除例は $20.6 \%$ にすぎず，このうち術前 に胆囊癌と正診された症例は77例（16.5\%）であった と報告している。

一方, 胆囊癌に結石が高率飞合併していることはよ く知られ，さらに結石非合併例の多くは腪胆管合流異 常を伴うことも報告されてきた ${ }^{21}$.これらの症例中に
は, 結石や脱落腫瘍組織の嵌頓から胆汁らっ滞をきた し, 急性化膿性胆露炎を併発し緊急入院する例がある。 今回, 過去 10 年問に浜松区療せンターで経騒した胆囊 癌例について，急性胆囊炎の併発例を検討した。

\section{自験例の成績}

昭和 47 年 4 月より約 10 年間に浜松医療センターで経 験した胆裹癌は52例であった。このらち急性胆霆炎を 併発し入院した症例は 7 例 (13.5\%) である（表 1$)$. 年齢は50歳から75歳をでで, 平均年路令は67歳であった。 男性 2 名, 女性 5 名である。

急性胆霊资の診断基準は牧野 ${ }^{374}$ によるそれに基づ

表 1 急性胆䤖炎を併発した胆囊癌症例

\begin{tabular}{|c|c|c|c|c|c|c|c|c|c|c|c|}
\hline 症例 & 年令 & 性 & 訴 & $\begin{array}{ll}\text { 発 } & \text { 病 } \\
\lambda & \text { 院 }\end{array}$ & $\begin{array}{ll}\lambda, & \text { 院 } \\
\text { 手 } & \text { 術 }\end{array}$ & (体)湿 & $\begin{array}{c}\text { WBC } \\
\text { (来院時) }\end{array}$ & T.bil & PTCCD & 細 菌培襄 & 胆裹造影 \\
\hline 1 & 63 & M & 嘔腹部哮 & 1 日 & 17日 & 37.7 & 13.000 & 1.15 & - & $\begin{array}{l}\mathrm{G}(-) \text { 桿菌 } \\
\mathrm{Eb} \text {. cloac }\end{array}$ & 陰 \\
\hline 2 & 69 & $F$ & 右季肋部痛 & 14日 & 16日 & 37.3 & 36.000 & 3.96 & + & $\begin{array}{c}\mathrm{G}(-) \text { 桿菌 } \\
\mathrm{E} . \text { coli }\end{array}$ & 陰 \\
\hline 3 & 75 & $F$ & $\begin{array}{l}\text { 発 熱 } \\
\text { 右季肋部痛 }\end{array}$ & 11日 & 10日 & 37.6 & 13,300 & 0.59 & - & $\begin{array}{c}\mathrm{G}(-) \text { 桿菌 } \\
\text { E. coli } \\
\text { Kle. pne. }\end{array}$ & 陽 \\
\hline 4 & 67 & $F$ & 心需部痛 & 9 日 & 1ヶ月 & 36.8 & 10.000 & 0.91 & - & 陰 & 陰 \\
\hline 5 & 73 & $F$ & 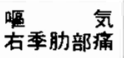 & 3 日 & 12日 & 37.6 & 19.200 & 1.18 & + & $G(+)$ 球菌 & 陰 \\
\hline 6 & 50 & M & 心窝部痛 & 18日 & 1ヶ月 & 40.2 & 12.800 & 0.35 & + & $\frac{\mathrm{G}(-) \text { 桿菌 }}{\mathrm{E} . \text { coli }}$ & 除 \\
\hline 7 & 73 & $F$ & 右季肋部痛 & 4 日 & 0日 & 37.2 & 11.200 & 1.47 & - & 陰 & - \\
\hline
\end{tabular}


く.つまり，1）右季肋下部に打いて死痛著明, 有痛性 腫瘤を触える、筋性防御を伴らなど，2）X線検査，超 音波検査で胆石の存在が明らかであるか, Nonfunctioning gallbladder が確認されている.3）急性资 症所見を有する，a）白血球数が一万以上，b） $38^{\circ} \mathrm{C}$ 以 上の発熱をみる. 自験 7 例の臨床症状は全例右季肋部 痛か心简部痛を主訴とし，白血球数はいずれも10,000 以上で最高36,000であった。

発病から入院までの期間が 1 週間以内の症例は 3 例 で，これらの症例は臨床所見の重い症例である。入院 から手術までの期間をみると，入院当日，緊急手術を した症例は 1 例で, 他は资症の消退を待って手術を施 行した。

入院当日，経皮経肝的胆囊ドレナージ（Percutaneous transhepatic cholecystography and drainage. 以下 PTCCD と略す) ${ }^{5}$ を施行した 3 例中 2 例に胆汁細胞診から術前, 胆囊癌と診断した。 PTC たは排泄性胆震造影で胆囊が陰性であったものは6例 中 5 例である。胆汁内細菌培養では 5 例に化膿菌を検 出した。

手術々式は, PTCCD を施行した症例 2 , 症例 5 が術 前に胆汁細胞診から class V と診断し，一期的に単純 胆摘兼肝床部の肝部分切除および所属りンパ節郭清か らなる拡大胆囊摘出術（以下拡大胆摘術々略す）を施 行した ${ }^{6 / 7)}$. 他の 5 例は術後, 胆囊癌と判明したもので, 深達度が筋層以上に浸潤していた 4 例中 2 例に二次的 拡大胆摘術を扣こなった(表 2$)$ 。肉眼的に胆囊はいず
れも化膿性胆囊炎を呈し，睡瘍の肉眼型では，乳頭型 3 例，結節型 1 例，浸潤型 2 例であった，病理学的に は, 7 例中 6 例 が adenocarcinoma で, 1 例 が adenoacanthomaである。

結石非合併例は，腪胆管合流異常を合併した症例 5 の 1 例である. 本症例は癌の壊死組織が嵌頓し急性胆 霬炎を併発したものであった.術後の成績は, Stage III の 2 例が死亡したが，他の 5 例は， 2 年 3 力月， 4 年 6 力月, 6 年 9 力月, 6 力月以内 2 例と生存中である.

\section{症例の提示}

症例 1.63歳, 男性

上腹部痛，呕吐を主訴として来院，入院時 WBC 13,000, T. Bil 1.15mg/dl である.PTCにて胆衰は造 影されず，総胆管に結石を認めた。炎症の消退を待っ て入院 17 日目に胆摘, 総胆管切開術を施行した。

切除胆囊には胆衰底部遊離腹腔側に $3.0 \times 2.5 \times 2.5$ $\mathrm{cm}$ の乳頭型腫瘤と結石を認めた（写真 1 ). 組織学的 には papillary adenocarcinoma で，漿膜下層までの 浸潤をみとめた。このため約 5 週間後，二次的扗大胆 摘術をおこなった。術後に MMC $40 \mathrm{mg}$ 投与を併用し， 6 年 9 力月現在健在である。

症例 5.73歳, 女性

右季肋部痛, 呕気を主訴に来院。入院時 $\mathrm{WBC}$ 19,200, T.Bil $1.18 \mathrm{mg} / \mathrm{dl}$. 急性胆囊炎の診断で PTCCDを施行した。胆汁は膿性で胆汁の吸引直後, 右 季肋部痛は消失した。採取した胆汁中の培養よりグラ ム陽性球菌を検出し，さらに胆汁中の細胞診にて

表 2 急性胆霝炎を併発した胆囊癌症例

\begin{tabular}{|c|c|c|c|c|c|c|c|c|c|}
\hline 症例 & 年令 & 性 & $\begin{array}{l}\text { 細 胞 診 } \\
(\text { PTCCD) }\end{array}$ & 手術所見 & Stage & 手術 術式 & 組 織 診 断 & 胆 石 & 子 \\
\hline 1 & 63 & $M$ & - & 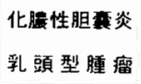 & I & $\begin{array}{l}\text { 二次的 } \\
\text { 桩大胆摘術 }\end{array}$ & $\begin{array}{l}\text { papil. adeno- } \\
\text { carcinoma }\end{array}$ & $\begin{array}{l}\text { 盟裹 } \\
\text { 総盟管 } \\
\text { ビ系石 }\end{array}$ & $\begin{array}{l}\text { 生存 } \\
6 \text { 年 } 9 \text { ヶ月 }\end{array}$ \\
\hline 2 & 69 & $F$ & class $V$ & 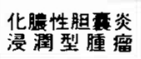 & III & 拡大胆摘術 & $\begin{array}{l}\text { mucin producing } \\
\text { adenocarcinoma }\end{array}$ & $\begin{array}{l}\text { 総䏣管 } \\
\text { コ系石 }\end{array}$ & $\begin{array}{c}\text { 死 } \\
6 \text { ケ }\end{array}$ \\
\hline 3 & 75 & $F$ & - & 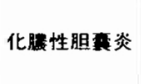 & I & $\begin{array}{l}\text { 腿 㒀 } \\
\text { 総胆管切開術 }\end{array}$ & carcinoma in situ & \begin{tabular}{|l} 
胆 毫 \\
綾胆管 \\
混合石
\end{tabular} & $\begin{array}{l}\text { 生存 } \\
4 \text { 年 } 6 \text { ヶ月 }\end{array}$ \\
\hline 4 & 67 & $F$ & - & $\begin{array}{l}\text { 化滕性胆 } \mathbf{A} \text { 炎 } \\
\text { 乳頭型腫癌 }\end{array}$ & III & $\begin{array}{l}\text { 胆 } \underset{\text { 摘 }}{\text { 及術 }} \\
\text { 総胆管切開術 }\end{array}$ & adenoacanthoma & $\begin{array}{l}\text { 胆 露 } \\
\text { 混合石 }\end{array}$ & $\begin{array}{l}\text { 死 } \\
1\end{array}$ \\
\hline 5 & 73 & $\mathrm{~F}$ & class V & 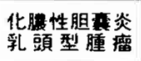 & II & 拡大胆摘術 & $\begin{array}{l}\text { papil. adeno- } \\
\text { carcinoma }\end{array}$ & & 生 2 年 3 ヶ存 \\
\hline 6 & 50 & $M$ & class I & 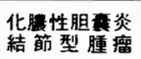 & III & $\begin{array}{l}\text { 二次的 } \\
\text { 搪大胆摘術 }\end{array}$ & $\begin{array}{l}\text { adeno-squamous } \\
\text { cell carcinoma }\end{array}$ & $\begin{array}{l}\text { 盟 衰 } \\
\text { 湿合石 }\end{array}$ & ヶ 集 \\
\hline 7 & 73 & $F$ & - & $\begin{array}{l}\text { 化虂性胆重资 } \\
\text { 浸潤型腫瘤 }\end{array}$ & III & 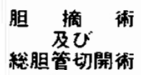 & $\begin{array}{l}\text { poorly diff. } \\
\text { adenocarcinoma }\end{array}$ & $\begin{array}{l}\text { 胆 衰 } \\
\text { 混成石 }\end{array}$ & $\begin{array}{ll}\text { 生 } & \text { 存 } \\
\text { 1 万 }\end{array}$ \\
\hline
\end{tabular}


写真 1 切除標本，底部の乳頭型腫瘤とビ系石

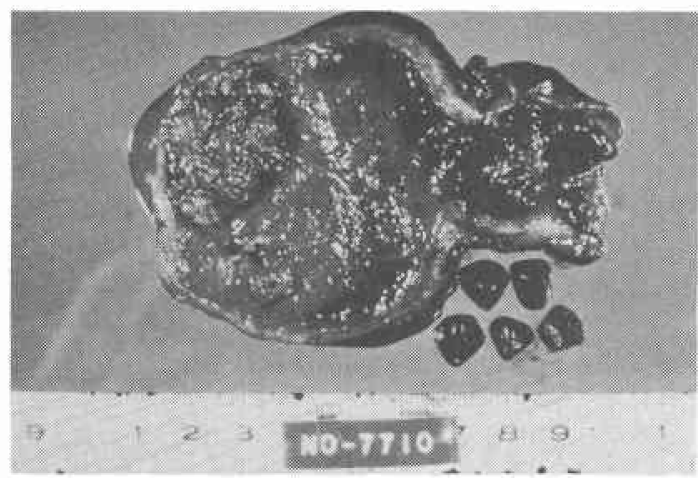

写真 2 胆䯧吸引細胞診. 膿性胆汁より証明された悪 性腫揚細胞

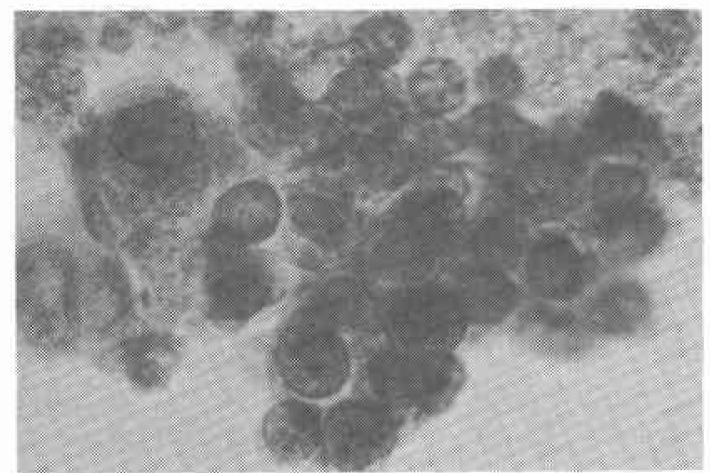

Class V と診断した（写真 2 ). 入院 12 日目に炎症の消 退を待って一期的に拡大胆摘術を扣こなった。結石は みられず, 胆囊, 総胆管内に癌の壊死組織が浮遊し, 胆囊底部に乳頭型腫瘤を認める(写真 3 )。組織学的に は papillary adenocarcinoma で漫達度 sl と診断さ れ, 術後に FT $207600 \mathrm{mg} /$ day, PSK 3.0g/day の経 口投与を併用し， 2 年 3 ヶ月の現在健在である。 症例 6.50歳, 男珄

右季肋部痛を主訴に来院. 急性胆囊炎の診断で PTCCDを抗こなった。䏣汁は膿性で細胞診では class I と診断した. ドレナージチューブよりの造影にて写 真 4 に示すような像を得た。胆囊は互いに交通をるつ

写真 3 切除標本. 表面のくずれた乳頭型腫瘤をみる. 結石はない。

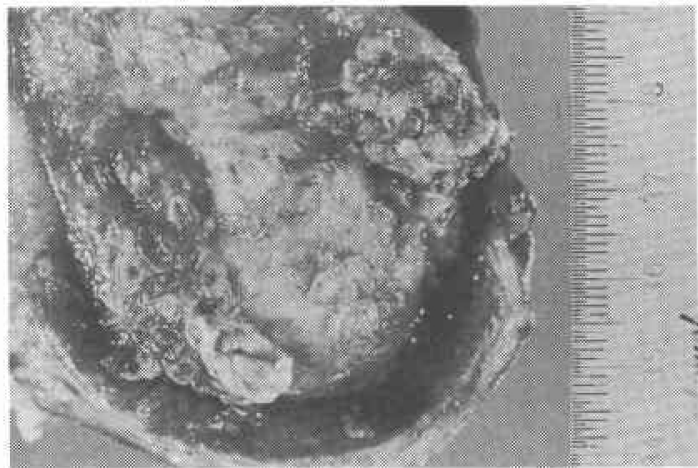

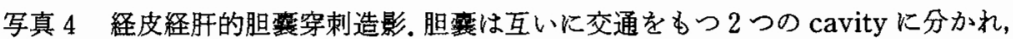
総胆管を左方に圧排している. PTCCD チューブは頝部側の胆亳内腔に插入されて いる。
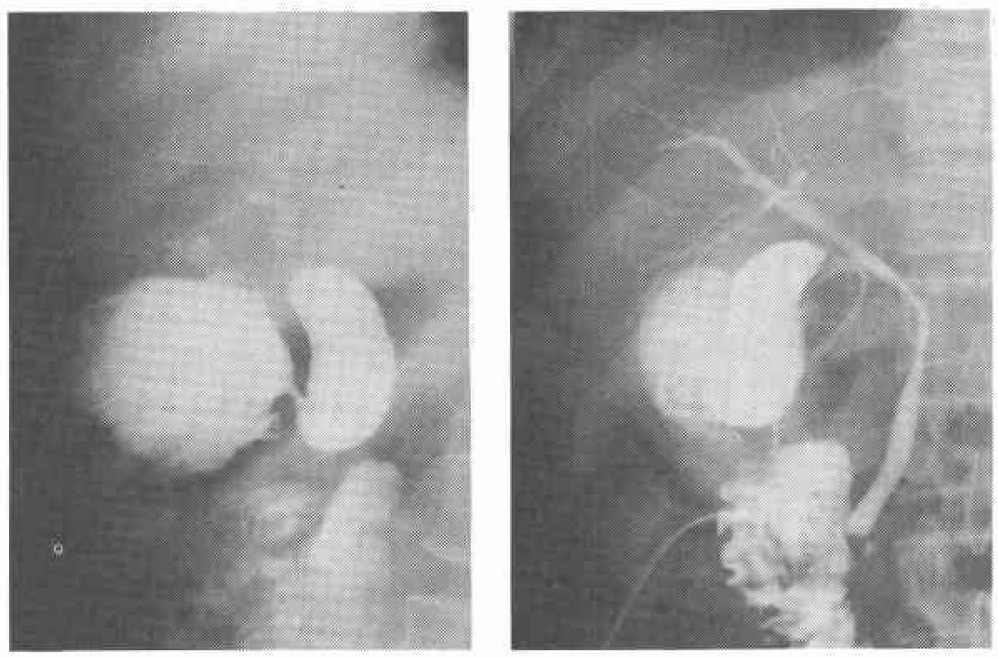
写真 5 切除標本. 胆囊内挖は隔壁と底部にある結節 型腫瘤によって二分され，圧排された細い管腔に よって交通を有す。

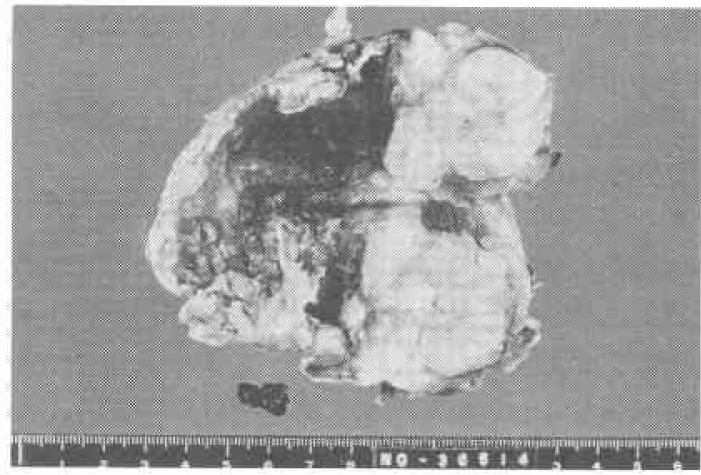

2つの cavityに分かれ，総胆管を左方に圧排している が，胆囊内の陰影欠損が腫瘤によるものとは認めがた い.さらに肝内胆管, 総胆管の拡張はみられず, 胆囊 底部の穿孔による周囲膿瘍之診断し開腹した。摘出し た胆囊は二分され，陰影欠損部が粘膜下に腫大した腫 瘤による王排狭窟であった。術後 stage III と診断し， 二次的拡大胆摘術を行った. 写真 5 は摘出胆亚である. 胆鸾底部に $5.0 \times 3.0 \times 3.5 \mathrm{~cm}$ の結節腫瘤をみとめる。 腫瘤にて中断された内腔は圧排された細い管腔として 頝部側と底部側の交通を有していた。ところが， PTCCDチューブの留置された頝部側は粘膜面に癌腫 の露出はなく粘膜下に腫瘤は増殖していた。このため PTCCDによる胆汁中の細胞診にて確診しえなかった と思われる。組織型は adeno-squamous cell carcinoma で, 術後 2 力月の症例である.

\section{考察}

胆囊癌は解剖学的特性より早期診断が困難であり, したがってその予後はきわめて不良である8) 10). 胆囊 癌の早期診断51112) に際しては, 胆囊の良性疾患に対 し，とくに高齢者では癌の併存 ${ }^{13)}$ 疑ってかかること が肝要である。今回，急性胆襄炎を併発した症例をと り上げたが14) 16).急性胆囊炎の原因として 90 から $95 \%$ は胆石が原因といわれている17)。しかし症例 5 のよう に，腫瘍の壊死組織の嵌頓によって急性胆襄炎を併発 する例がある。Thorbjarnarson ${ }^{15)}$ は, 胆囊癌症例の 11\%に急性胆囊炎を併発し，一方急性胆囊炎の診断で 手術した症例の $1 \%$ に胆囊癌をみとめたと報告してい る。われわれのもつ症例の頻度は52例中 7 例で $13.5 \%$ に急性胆囊炎を併発していたことになる。急性胆囊炎 を呈した症例に対する PTCCDの目的は診断と治療
の両面である。土屋ら ${ }^{5}$ は胆襄癌確診例26例の胆汁細 胞診で24例（92.3\%）に悪性腫瘍細胞がみられたのに 対し，胆囊炎12例では 1 例の陽珄例もみられないと報 告している。また著者ら ${ }^{18)}$ は経皮的胆覇造影を行った 57例を対象にその有効性を検討したところ経皮的胆震

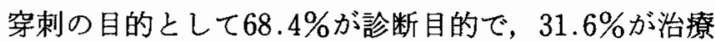
目的であった。さらに57例中33例に胆汁細胞診から class IV〜V と診断した，治療を目的に緊急の経皮経 肝的胆囊ドレナージを施行した14例の急性化膿性胆囊 炎例では全例その臨床的効果は顕著であった。

術前に胆囊癌と診断することは，術式選択上重要な ことで，PTCCDからの胆汁吸引細胞診はきわめて有 意義である。

\section{結語}

急性胆囊炎を併発した胆囊癌 7 例について検討し た。

(1) 7 例を Stage 別に分類すると Stage I 2 例， Stage II 1 例, Stage III 4 例であった.

(2) 治療目的に施行したPTCCDょりの胆汁細胞診 から 2 例を胆囊癌と確診し，一期的拡大胆摘術を施行 した。

(3) 7 例中 6 例は結石を合併したが，1 例は非結石合 併例である。

以上の(1)(2)の結果から急性胆囊炎では常に胆囊癌 の合併を考慮し対処すべきで，超音波下に施行する PTCCD は治療と診断の面から価値あることを強調し たい.

\section{文献}

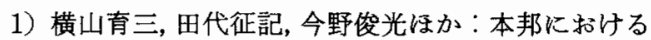
胆震癌の外科療法の趨勢。日消外会誌 13 : $1362-1369,1980$

2) 木下博明, 長田栄一, 街 保敏㳗か：腪胆管合流異 常を合併した胆裳癌. 胆と桠 $2: 1701-1709$, 1981

3）牧野永城：急性胆襄炎一早期手術の是非。日医新 報 $2596: 11-15,1973$

4) 西尾剛毅, 湘瀬信太郎, 牧野永城：急性胆囊炎の治 療一術のタイミング. 臨外 $34: 1535-1538$, 1979

5）土屋幸治, 大藤正雄, 仲野敏彦注か：胆桽癌に打け る胆哓穿刺診断の意義一細胞診扔よびX 線造影 について，腹部画像診断 $2: 49-58,1982$

6）伊関丈治, 牛山孝樹, 別府倫兄ほか：胆囊癌切除症 例の検討. 日消外会誌 $16: 607-612,1983$

7）佐藤寿雄，小山研二：胆囊癌に対する払大根治手 術一いわゆる拡大胆摘術の遠隔成績の反省から. 消外 5:191-197，1982 
8）宮崎逸夫, 永川宅和：胆道癌取扱い規的と胆囊癌 の予後. 消外 5:207-212, 1982

9) Ohlsson EG, Aronsen KF : Carcinoma of the gallbladder-A study of 181 cases. Acta Chir Scand $140: 475-480,1974$

10) Donaldson LA, Busuttil A: A clinicopathological review of 68 carcinomas of the gallbladder, Br J Surg 62:26-32, 1975

11）伊藤信義, 高橋 徳：胆襄癌の診断. 消外 5 ： $165-172,1982$

12）横山育三, 田代征記：胆衰癌の診断と治療. 木本誠 二監修。現代外科学大系, 年間追補78C, 東京, 中 山書店, 1978, p183-219

13) Marcial-Rojas RA, Medina R: Unsuspected carcinoma of the gallbladder in acute and chronic cholecystitis. Ann Surg $153: 289-298$, 1961
14）笠原 洋, 川合秀治, 松本博城ほか：胆囊癌一砂時

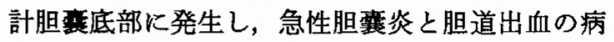
像を呈した 1 例。日外宝 $47: 730$-738，1978

15) Thorbjarnarson B: Carcinoma of the gallb ladder and acute cholecystitis. Ann Surg 151 : 241-244, 1960

16) Person DA : Carcinoma of the gallbladder presenting as acute cholecystitis and leading to a missed clinical and pathologic diagnosis. Am J Surg 108 : 95-97, 1964

17）瀬戸口敏明，香月武人：急性腹症としての胆石症 扣よび急性胆鸾炎. 外科治療 $45: 285-289,1981$

18）内村正幸, 脇 慎治, 木田栄郎ほか：経皮経肝的胆 震ドレナージ。胆と膵 $4: 19-26,1983$

19）日本胆道外科研究会編：外科胆道癌取扱い規約. 東京, 金原出版, 1981 